\author{
Mona Erfanian Salim \\ https://orcid.org/0000-0002-8012-2205 \\ Faculty of Architecture and Urban Planning \\ Institute of Higher Education of Eqbal Lahoori, Mashhad, Iran \\ monaerfanian@gmail.com
}

\title{
IMPROVING QUALITY OF LIFE THROUGH THE PLACE BRANDING OF THE LASHKAR ABAD NEIGHBORHOOD IN AHWAZ (IRAN)
}

\begin{abstract}
Iran has many tourism assets in its cities which can be developed by place branding and destination marketing. Anousheh Street in the Lashkar Abad neighborhood of Ahwaz shows good practice in this field. It is a dynamic and active public space in a tourism context that has become well-known in spite of its inappropriate economic and social background. This article describes the process of change. For this purpose, it uses the analysis based on interviews with stakeholders. It indicates features modelled on the principles of place branding. The results show how urban development can be enhanced relying on tourism assets. Keywords: quality of life, place branding, tourism assets, Ahwaz (Iran).
\end{abstract}

\section{POPRAWA JAKOŚCI ŻYCIA POPRZEZ BRANDING MIEJSCA NA PRZYKŁADZIE DZIELNICY LASHKAR ABAD W AHWAZ (IRAN)}

Abstrakt: Miasta współczesnego Iranu posiadają wiele walorów turystycznych, w oparciu o które można budować markę miejsca. Ulica Anousheh w dzielnicy Lashkar Abad w Ahwaz reprezentuje dobre praktyki w tym zakresie. Jest to dziś dynamiczna przestrzeń publiczna w kontekście turystyki, która stała się znana pomimo nieodpowiedniego zaplecza gospodarczego i społecznego. Autorka artykułu, wykorzystując m.in. analizę wywiadów z interesariuszami, przedstawia proces zmian i eksponuje aspekty oparte na zasadach brandingu miejsca. Wyniki pokazują w jaki sposób można poprawić rozwój obszarów miejskich w oparciu o walory turystyczne.

Słowa kluczowe: jakość życia, branding miejsca, walory turystyczne, Ahwaz (Iran).

\section{INTRODUCTION}

Ashworth (2009), based on one definition of place branding, considered it created "a sense of place that can for example legitimate those in power, facilitate a sense of belonging and local pride among the residents and attract identified target groups in pursuit of economic growth" (Hass, 2013). However, Anholt (2010) defines place branding as "the practice of applying brand strategy and other techniques and disciplines - some deriving from commercial practice and others newly developed - to the economic, social, political and cultural development" of places, emphasizing the tools used in the process. This paper attempts to show how a community can establish place branding in a way that consequently leads to the enhancement of the quality of life and urban development. It is in two parts: the first part reviews the literature to show the relationship between place branding and quality of life in the context of urban development. The findings help to specify the experience of Lashkar Abad neighborhood in Ahwaz (a city in Iran). In the second, parts of a large research project that investigates urban regeneration practices in Iran by concentrating on the quality of life were applied. It was carried out in Anousheh St in the Lashkar Abad neighborhood of the city of Ahwaz.

Considering the issues discussed, and knowledge of the importance of the quality of life in the development of societies, the Iranian Urban Regeneration Corporation developed a biannual event to identify and recognize the experiences that have brought a sustainable sense of quality to the people and practical guidelines for local governments. It directly confronts the urban regeneration approach and the quality of urban life. In fact, "The National Quality Award for Urban Regeneration Practices in Iran" has been organized to sensitize professional and academic communities about the concept of quality and the necessity of operational attention to this concept. To compile evaluation criteria, three main steps were taken. The first involved systematic identification and analysis of documents containing information related to the concept of the quality of life 
with respect to urban regeneration. The second step was interviewing a group of 25 selected urban experts whose ideas and suggestions were gathered and analyzed by using the focus group method. At the third step, criteria were revised and indicators were extracted, and then three consultation meetings were held in order to verify the extracted indicators and sub-indicators according to a project typology.

In order to assess the status of the evaluation criteria in the case study, which were directly effective in improving the quality of urban life, the next step focused on 'Data Collection' and 'Analysis and Interpretation of Collected Data' about the case. The data collection process included revision of written documents and all available data in local organizations about Anousheh Street and checking of the documents provided (according to compiled criteria). Consequently, by using the 'Participant Observation Method', the author tried to get first-hand understanding of the practice. Finally, the author interviewed local people at a defined distance from an activity center in order to find agreement or to deny the effectiveness on improving the quality of life. It indicates the features of this practice based on place branding principles. The results show how urban development can be enhanced based on tourism assets. Moreover, other tourism destinations with similar conditions could conduct them.

\section{PLACE BRANDING AND LOCAL DEVELOPMENT}

Over the past 20 years, place branding has been increasingly considered as a basic part of local and regional development strategies (Cleave, Aruk, Sadler, Gilliland, 2016). Place branding contains a series of place-based elements including place marketing, place expressions, the actions and attitudes of the stakeholders, and local infrastructure quality (Hall, Hubbard, 1996; Kavaratzis, 2004; Cleave, Aruk, Sadler, Gilliland, 2016). Therefore, place-branding policy is a tool for attracting and retaining business to influence the development of a place (Cleave, Aruk, Sadler, Gilliland, 2016). In this regard, the notion of place branding has gained attention from policy makers and academics as well from governments that care about developing places (which could be countries, regions, towns or cities) by creating or discovering their individuality and identity (Hass, 2013). On this basis, the branding of places is increasingly applicable as a strategy for development, and the practices of place branding have grown during this time (Hass, 2013). It can also have an important role in the sustainable development of a place, while maintaining the momentum of progress (Maheshwari, Vendewalle, Bamber, 2016). In addition, Anholt (2010) believes that the majority of countries and cities who claim to exercise 'branding', in fact actually produce just a "modest process of livery enhancement and coordination". Although, in the process of local development, local governments need to know their assets realistically and understand opportunities for future growth (Cleave, Aruk, Sadler, Gilliland, 2016). Dominiguez García, Horlings, Swagemaker, Simón Fernandez (2013) during a review of some cases indicated that "branding as a strategy for a territorial development strategy can be successful". The cases showed that balancing different aspects of sustainability, the development of products and services rooted in territorial capital and organization, and the alignment of stakeholders under a joint umbrella vision, are key ingredients of a branding process (Dominiguez García, Horlings, Swagemaker, Simón Fernandez, 2013). Therefore, the relation between place branding and local development can be studied in two ways: internal and external.

As Ornston (2014) and some other researchers have mentioned (Cleave, Aruk, Sadler, Gilliland, 2016) "In terms of, local economic development, a 'low-road' policy implies a narrow set of homogenized policy initiatives, characterized by low-end prescriptive activities that propagate and are mimicked among many places". Place branding acts as competition in the domain of economic development leading to the improvement of local attributes and resources towards the development of 'sticky places' and creating benefits for other markets (Cleave, Aruk, Sadler, Gilliland, 2016). Dominiguez García, Horlings, Swagemaker, Simón Fernandez, (2013), identifies three mutually reinforcing processes in the development of an internal brand:

(i) increasing 'visibility' (referring to awareness and identification of cultural values and markers), (ii) the development of new products and services (i.e. placebased product innovation) and (iii) the reorganization of activities (including regional governance and cooperation).

These processes usually run parallel. The following will introduce how these three aspects play a role on Anousheh Street in the Lashkar Abad neighborhood.

From a sustainable development perspective, place branding provides an opportunity for local actors to play a role in sustainable territorial development (Dominiguez García, Horlings, Swagemaker, Simón Fernandez, 2013). They utilize and improve resources like food, water, nature, and leisure space instead of degrading them (Dominiguez García, Swagemakers, Bock, Simón Fernandez, 2012). This process of adaptation causes an improvement of building alliances and the development of networks of entrepreneurs and citizens who value local assets and are rooted in socio-cultural concepts of regional identity. Such place-based routes reveal an overhanging regional scenario that needs to be mobilized in the regional economy and society (Domini- 


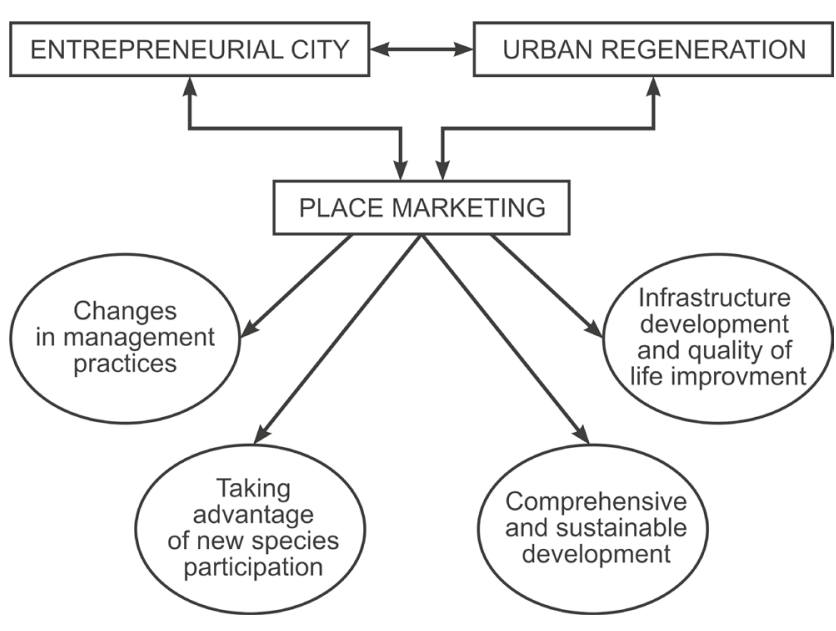

Figure 1. The proposed conceptual framework for urban regeneration and city entrepreneurship interaction in achieving place marketing

Source: Rafieiyan and Mohammadi Aydaghmish (2017)

guez García, Horlings, Swagemaker, Simón Fernandez, 2013). Oliveira and Henrique (2016) emphasizes that proper governance processes may lead to increased social and political cohesion by constructing a sustainable place-branding strategy that has been undertaken in response to comparable place brands elsewhere. This policy applies especially to areas where physical revitalization or urban regeneration or other forms of structural, socio-economic change is needed (Cleave, Aruk, Sadler, Gilliland, 2016; Oliveira, Henrique, 2016). On this basis, spatial planning strategies can contribute to marketing and branding as well as to urban regeneration (Oliveira, Henrique, 2016). Some academics believe that place marketing and branding are "strategic processes contributing to urban/regional development and urban/ regional competitiveness" (Deffner, 2010; Oliveira, Henrique, 2016). Today, both marketing and urban planning can be considered as an effect of institutional political ideology and influence each other. Rafieyan and Mohammadi Aydaghmish (2016) through reviewing the literature propose a conceptual framework of urban regeneration and an entrepreneurial city in achieving place marketing (Figure 1). This study shows some changes based on urban regeneration that have brought about some changes in managerial systems, and corporate governance at the same level as market motivation and building capacity. It seems the beginning of a new type of participation which aims to improve infrastructure and increase the quality of life (Rafieiyan, Mohammadi Aydaghmish, 2017).

\section{PLACE BRANDING AND IMPROVING THE QUALITY OF LIFE}

Since place branding and urban development can go in the same direction, urban development indicators can be considered in relation to place branding and marketing. Literature on the relationship between urban planning and place branding highlights quality as an indicator related to development (Quality Indicator..., 2011). Cusin and Damon (2010) point to many indexes assessing place that are indicators of the popularity and variety of current place marketing practices (Vuignier,

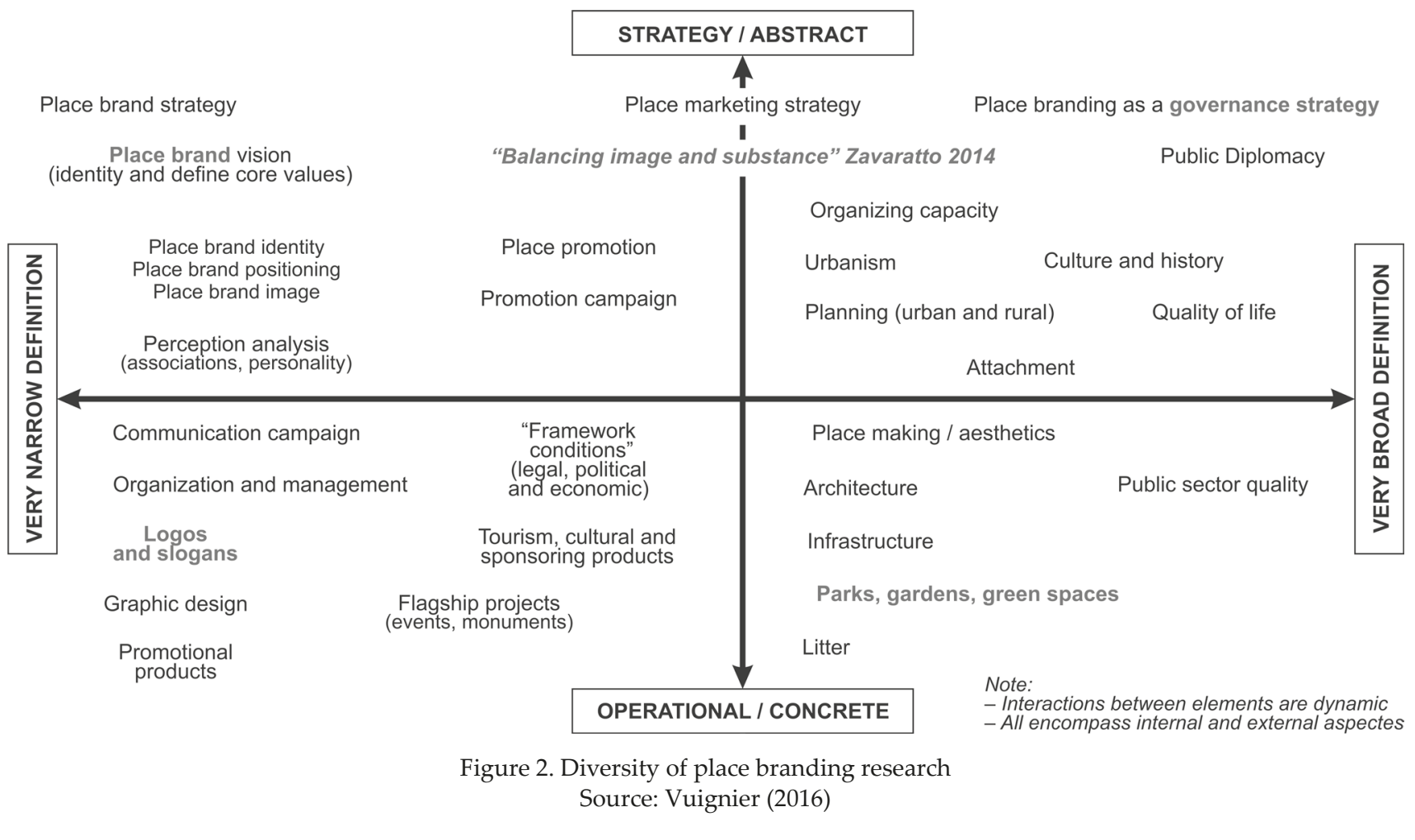


2016). In fact, both branding and marketing activities by tools such as promotional campaigns, events and highlighting the places, support aims to improve the quality of a place (Vuignier, 2016).

Furthermore, Yazdanpanah Shahabadi, Sajadzadeh, Rafieyan (2019) indicate "brand strategy entered the field of urban development, regeneration and quality of life from the business world". Vuignier (2016) refers to Florek and Insch (2011), Zenker and Rütter (2014) to illustrate that "the literature addresses very broad concepts of place branding, like culture and history, place attachment and quality of life (Figure 2)". In tangible terms, it means the target groups' perception of the quality of life and public sector quality is part of place branding.

Thus, place branding causes "increasing place prestige, added value, increasing investment in the place, attraction of creative social classes, economic, social, and cultural privileges for the inhabitants as a result of their involvement in the process of place branding, and enhancement of environmental qualities as well as functional refinement of the place" (Yazdanpanah Shahabadi, Sajadzadeh, Refiejan, 2019). Place branding is going to provide a good reputation for a place and increase residents' place attachment. The place brand is "a set of thoughts and feelings while quality of life improvement so gives a 'sense of attachment' among residents and 'sense of place' among the external audiences of the place" (Yazdanpanah Shahabadi, Sajadzadeh, Refiejan, 2019).

\section{THE LASHKAR ABAD NEIGHBORHOOD IN AHWAZ}

Ahwaz is one of the eight metropolitan cities of Iran and is located in the south west of the country; the capital of Khuzestan province. This city is home to Persians, Arabs and Lurs so different languages are spoken there such as Persian, Arabic, the Persian dialects of Lori (Bakhtiari), Dezfuli, Shushtari etc. The Karoun river, which is Iran's only navigable river, passes through the middle of the city. At present, the city has eight municipal areas, each including of three or four districts. Lashkar Abad neighborhood is in the $4^{\text {th }}$ district. Nowadays, Anousheh Street in this neighborhood is one of the main tourism attractions of the city.

According to statistics and information, Ahwaz has a special status in terms of its degraded urban fabric and informal settlement that make the city need to be considered for various reasons. Some depend on the historical background of Khuzestan province and others on issues related to the Iran-Iraq war and its situation near to the western border. Currently, about $20 \%$ of Khuzestan's 4.5 million population live in areas lower than average urban quality. Ahwaz Municipality Renovation and Improvement Organization reveals that $30-35 \%$ of Ahwaz is known for its degraded fabric and informal settlement and so a housing empowerment plan has been prepared to control inappropriate economic and social effects and to make the public space of Anousheh Street more active in a tourism context.

\section{THE POINTS OF DEPARTURE FOR DEVELOPING AN INTERNAL BRAND FOR THE LASHKAR ABAD NEIGHBORHOOD}

In recent decades, some changes have happened in the Lashkar Abad neighborhood (Figure 3). The results of data collection (including current statistics, as well as field study with observations and interviews with stakeholders) illustrate that the changes initiated by the local community in this neighborhood have not only transformed it into a main tourism attraction of the
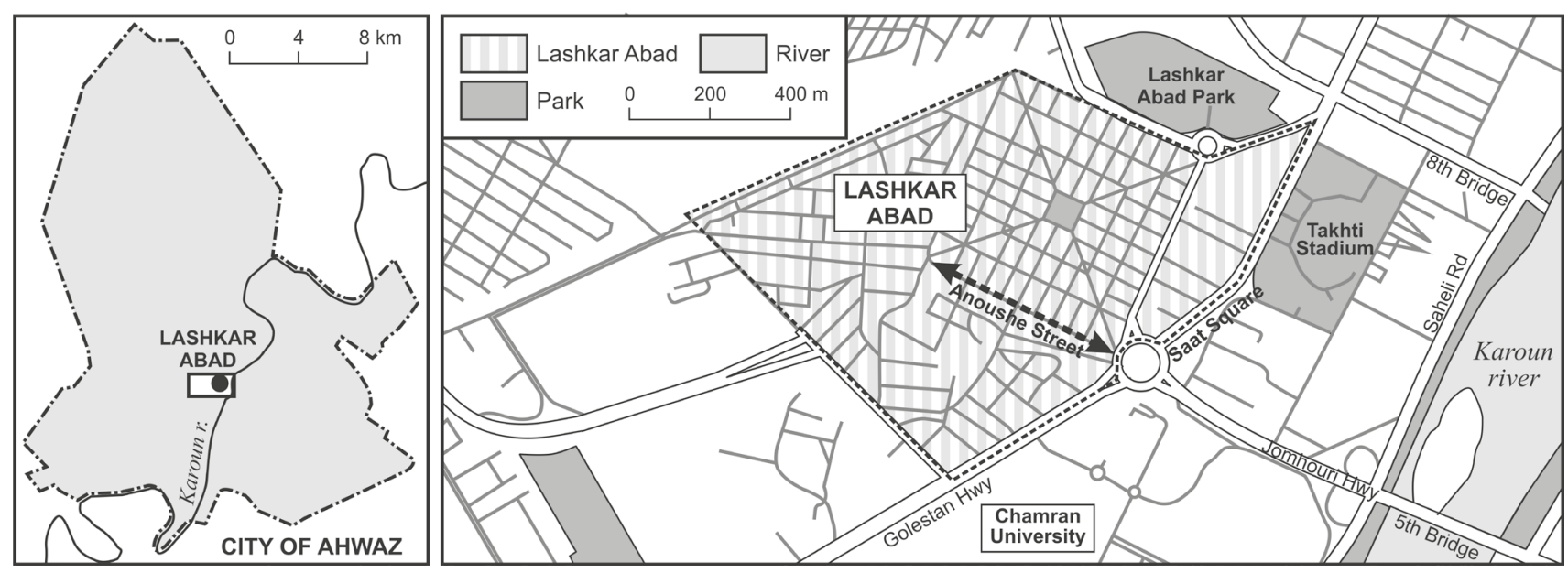

Figure 3. Location of Lashkar Abad

Source: Management of Planning and Statistics Development, Ahwaz Municipality (2017) 
city but also initiated the process of urban regeneration. During this time, the local community have started to improve their lives by selling local foods, above all through small shops. Based on interviews with the people and local government, this process began with the establishment of a 'deli' by a local woman and it was followed by the opening of many other cheap fast food restaurants. They serve local food with a special type of buffet that lets people make 'sandwiches' by themselves and then they expanded and opened shops. This work proved profitable and they started using their houses as places for serving food and other services. People found this street much more satisfying than before and residents could make a good income; its face was changed from a place for criminals to a place that families visit, open 24 hours a day, to spend time and to eat. The street's structural and economic enhancement affected the lifestyle of the residents, and young people from the community could find work. On the other hand, the increase in the value of properties on this street and nearby is much moreimportant for them. Another positive point is the increase in security that originates from communication between Lashkar Abad and adjacent districts.

As mentioned above by Dominiguez García, Horlings, Swagemaker, Simón Fernandez (2013), there are three mutually strengthening processes in the development process of an internal brand. The process that happened in Lashkar Abad is investigated based on the following three items.

1. Increased 'visibility': refers to the awareness and identification of cultural values and markers. The results of the interviews highlight a number of changes in the cultural and social contexts of the neighborhood during recent years. Panbedaneh (Executive Director of the Municipality) mentions in 2016 that in Anousheh Street the change of cultural context (which is itself a social change) is the same as the physical context of Anousheh Street. However, "Nowadays, this pathway is a center for traditional vendors, food sellers, cafes, and restaurants and it is so much more entrepreneurial" (Pazhotan, 2018).

2. The development of new products and services, place-based product innovation: the first by a local woman on Anousheh Street was simple inexpensive food and then other foods such as samosas came along. Serving these dishes with a free buffet of a variety of pickles and delicacies is a specific style that is nowadays used in many Iranian cities. In addition, the residents established traditional cafes, serving tea and Arabic coffee. Based on the report of Ahwaz Municipality, about 2,500 people are currently directly involved in these activities and more interestingly,

Table 1 . The results of field interviews with stakeholders about the quality of life

\begin{tabular}{|c|c|c|}
\hline Macro criterion & Sub-criteria & $\begin{array}{l}\text { Rank } \\
\text { (order of importance } \\
\text { from } 10 \text { to } 1 \text { ) }\end{array}$ \\
\hline $\begin{array}{l}\text { Enhancement of happiness } \\
\text { and vitality }\end{array}$ & $\begin{array}{l}\text { Ease of access (personal, public transport, pedestrian access). } \\
\text { Social (age, gender, physical) and cultural inclusion. } \\
\text { The variety of programs offered and the continued presence of people } \\
\text { in the public arena. } \\
\text { Improved safety. } \\
\text { Improving social security and property security of the local community } \\
\text { and citizens. } \\
\text { Improving the mental image of the local community and citizens from } \\
\text { space (with the aim of promoting the neighborhood's status to other } \\
\text { citizens). }\end{array}$ & $\begin{array}{l}6 \\
7 \\
9 \\
5 \\
4 \\
8\end{array}$ \\
\hline $\begin{array}{l}\text { Economic prosperity and } \\
\text { improving the livelihood } \\
\text { of the local community } \\
\text { (residents-users-business) }\end{array}$ & $\begin{array}{l}\text { Desirable impact on the process of building improvements while } \\
\text { preventing the forced migration of the local community. }\end{array}$ & 10 \\
\hline Creative conceptualism & $\begin{array}{l}\text { Considering the socio-cultural structures and behavior patterns } \\
\text { of different citizen groups. }\end{array}$ & 2 \\
\hline Participatory management & $\begin{array}{l}\text { Active involvement of people at different stages of the program process } \\
\text { (needs assessment, solution delivery, prioritization of action, } \\
\text { implementation, operation). }\end{array}$ & 3 \\
\hline $\begin{array}{l}\text { Preserving and improving } \\
\text { the environment }\end{array}$ & Maintain and enhance local ecosystems. & 1 \\
\hline \multicolumn{3}{|l|}{ Conclusion } \\
\hline \multicolumn{3}{|c|}{ Aligning the vision that governs the program and the goals set with its actions and achievements } \\
\hline \multicolumn{3}{|c|}{ Programmatic creativity and innovation + application: innovation in service delivery } \\
\hline
\end{tabular}

Source: Pazhotan (2018). 
another 2,500 support them. That is a figure of nearly 5,000 who, without much government investment, are experiencing significant economic growth.

3. The reorganization of activities (including regional governance and cooperation): in any region where economic growth is taking place, because of its balanced development, a number of others occur in parallel. Fortunately, municipal officials and urban planners have accepted this. That is to say, as Anousheh Street has spontaneously changed from its former form, urban planners will go along with this and will develop urban plans and programs in line with economic, cultural and urban development. That is why it has become a tourism axis, a place brand in the city for whole of the country.

In Anousheh Street when the work began, it was done by the people themselves and in a completely spontaneous and popular way based on their culture and belonging which led to prosperity followed by urban regeneration (Pazhotan, 2018). Urban plans for Ahwaz generally mention Lashkar Abad as a model gained from the experience and, therefore, the government has followed this model in some other cities.

As mentioned in the introduction, this study also gives some data that illustrate that the quality of life is improving in Lashkar Abad (Table 1).

Social cohesion is the most important factor in the formation and identification of the market and the tourism attraction index is the most important spatial consequence of the formation of Anousheh Street. It was also determined that economic, social and physical factors are elements influencing the sense of place in this neighborhood and in proportion to the increase and improvement of these indices, the sense of place in the market of Anousheh Street in Ahwaz has increased. In sum, the citizens have a very important role in creating markets, and consequently, these markets create economic impacts (businesses, attracting customers and tourists) with social and cultural influences. The project creates social solidarity and a sense of belonging, and also increases and changes the adverse perception of other citizens of the Ahwaz metropolitan area. Lastly, the market and the efforts of residents and busi nesses create and enhance a safe space for customers and tourists and the physical change of the market which emphasizes the role of the reconstruction of the city fabric that has happened in the Lashkar Abad neighborhood (Shaikh Aleepour, 2017).

\section{CONCLUSION}

This paper has illustrated the relation between place branding and economic development that can improve the quality of life in a neighborhood. The case study with a qualitative approach to assessing the prosperity of an urban practice can develop a people-based evaluation system in order to achieve a set of actions compatible with public priorities and expectations. The process that will subsequently lead to a bilateral learning stream among people and experts. The emphasis lies on two issues: 1 . Developing the concept of the quality of life when considering its informal perception among the local community and the common knowledge derived from it which can guide urban planning and design toward an improvement in the quality of urban life. 2. Developing some 'lessons learned', in order to create a more realistic understanding about the accomplishment of decision-makers. The investigation of Lashkar Abad practice shows that the local community has a key role in initiating the branding process rather than decision makers. It also proves that decision-makers and urban planners support the social and economic changes created by local community.

\section{BIBLIOGRAPHY}

Anholt, S. (2010). Definitions of place branding: Working towards a resolution place branding and public diplomacy. Place Branding and Public Diplomacy, 6 (1), pp. 1-10.

Ashworth, G. (2009). The instruments of place branding: how is it done? European Spatial Research and Policy, 16 (1), pp. 9-22.

Cleave, E., Aruk, G., Sadler, R., Gilliland, J. (2016). The role of place branding in local and regional economic development: Bridging the gap between policy and practicality. Regional Studies, Regional Science, 3 (1), pp. 207-228.

Deffner, A., Metaxas, T. (2010). Place marketing, local identity and branding cultural images in Southern Europe: Nea Ionia, Greece and Pafos, Cyprus. In: G. Ashworth, M. Kavaratzis (eds.), Towards effective place brand management. Branding European cities and regions. Cheltenham: Edward Elgar Publishing.

Dominguez Garcia, M.D., Swagemakers, P., Bock, B.B., Simón Fernandez, X. (2012). Making a living: grassroots development initiatives, natural resource management and institutional support in Galicia, Spain, European Countryside, 4 (1).

Dominiguez García, M., Horlings, L., Swagemakers, P., Simón Fernández, X. (2013). Place branding and endogenous rural development. Departure points for developing an inner brand of the River Minho estuary. Place Branding and Public Diplomacy, 9 (2), pp. 124-140.

Florek, M., Insch, A. (2011). When fit matters: Leveraging destination and event image congruence. Journal of Hospitality Marketing \& Management, 20 (3-4), pp. 265-286.

Hall, T., Hubbard, P. (1996). The entrepreneurial city: New urban politics, new urban geographies? Progress in Human Geography, 20 (2), pp. 153-174.

Hass, L.D. (2013). A review of the notions of place branding and place identity in literature. Wageningen: Wageningen University.

Kavaratzis, M. (2004). From city marketing to city branding: Towards a theoretical framework for developing city brands. Place Branding, 1 (1), pp. 58-73.

Maheshwari, V., Vandewalle, I., Bamber, D. (2016). Place branding's role in sustainable development. Journal of Place 
Management and Development 4 (2), pp. 198-213, https://doi. org/10.1108/17538331111153188

Oliveira, D.S., (2016). Place branding in strategic spatial planning: An analysis at the regional scale with special reference to Northern Portugal. Doctoral disertation. Groningen: University of Groningen.

Ornston, D. (2014). When the high road becomes the low road: The limits of high tech competition in Finland. Review of Policy Research, 31 (5), pp. 454-477.

Pazhotan, E. (2018). Reports of the Event "The second National Award for Urban Regeneration Practices". Haft Shahr, 59\&60.

Quality Indicator Measure Development, Implementation, Maintenance, and Retirement (Prepared by Battelle, under Contract No. 29004-0020). Rockville, MD: Agency for Healthcare Research and Quality (May 2011).

Rafieiyan, M., Mohammadi Aydaghmish, F. (2017). Proposing a conceptual framework of urban regeneration interaction and entrepreneur city in achieving place marketing. Journal of Urban Economics and Management, 5, 2 (18), pp. 1-20.
Shaikh Aleepour, R. (2017). An evaluation into consequences of forming anoshe street arcade in Lashkar Abad neighbourhood of Ahwaz city. Ahwaz: s.n.

Vuignier, R. (2016). Place marketing and place branding: A systematic (and tentatively exhaustive) literature review. (Working Paper d l'IDHEAP, 5/2016), https://hal.archives-ouvertes.fr/ hal-01340352/document

Yazdanpanah Shahabadi, M., Sajadzadeh, H., Rafieyan, M. (2019). Developing a conceptual model for place branding: A reviw on teoritical literature. Bagh-e Nazar, 16 (71), pp. 19-34.

Zenker, S., Rütter, N. (2014). Is satisfaction the key? The role of citizen satisfaction, place attachment and place brand attitude on positive citizenship behavior. Cities, 38, pp. 11-17.

Artykuł wpłyną: 16 czerwca 2018 Zaakceptowany do druku: 10 grudnia 2018 